\title{
Cellular immunohistopathology of acute, subacute, and chronic synovitis in rheumatoid arthritis
}

\author{
YRJÖ T KONTTINEN, ${ }^{1}$ VILLE BERGROTH, ${ }^{1}$ DAN NORDSTRÖM ${ }^{1}$ \\ KALEVI KOOTA, ${ }^{2}$ BO SKRIFVARS, ${ }^{1}$ GÖSTA HAGMAN, ${ }^{3}$ \\ CLAES FRIMAN, ${ }^{2}$ MARTTI HÄMÄLÄINEN, ${ }^{2}$ AND PÄR SLÄTIS \\ From the ${ }^{1}$ Fourth Department of Medicine, Division of Rheumatic Diseases, Helsinki University Central \\ Hospital, the ${ }^{2}$ Rheumatism Foundation Hospital, Heinola, and the ${ }^{3}$ Surgical Hospital, Division of \\ Orthopaedic Surgery and Traumatology, Helsinki University Central Hospital
}

SUMmARY Cellular inflammation in rheumatoid arthritis (RA) synovial membrane was studied in biopsy specimens taken at different stages of synovitis and disease. Patients were classified into three subgroups: acute RA, subacute RA, and chronic RA. Inflammatory cells were characterised by a histochemical esterase method and immunohistochemical peroxidaseantiperoxidase (PAP) and avidin-biotin-peroxidase (ABC) staining.

The amounts and distribution of inflammatory cells were different in various stages of the synovitis. In acute onset RA monocytes and granulocytes predominated, suggesting that the beginning of rheumatoid inflammation is similar to inflammatory reaction in general. The presence of $T$ cells and also of plasma cells in subacute RA suggests underlying subclinical changes also in apparently healthy joints in RA. The most typical feature of prolonged synovitis in chronic RA was its intensity, characterised by the presence of large $\mathrm{T}$ cell and plasma cell infiltrates. Our findings suggest that the immunological mechanisms are secondary to the tissue damage caused by the initial inflammatory events of unknown cause. However, the immunological mechanisms may still play a central role in the aetiopathogenesis, because findings in chronic RA suggest a defective down-regulation of the immune response.

Inflammation in rheumatoid synovial tissue in chronic RA has been exhaustively characterised by different histological, histochemical, immunological, and immunohistochemical methods. ${ }^{1-8}$ However, the histopathological pattern observed in chronic RA may present an end stage in a prolonged disease. This is supported by two earlier publications on synovitis of recent onset, where histopathological findings quite different from those observed in chronic synovitis in RA were reported. ${ }^{9}{ }^{10}$ These studies by Kulka et al. ${ }^{9}$ and Schumacher and Kitridou $^{10}$ dealt with the morphological findings at light microscopic and electron microscopic level. We therefore decided to extend their work to cellular immunohistopathology of synovitis of recent onset. This is the final report of a collaborative study

Accepted for publication 5 March 1985.

Correspondence to Dr Yrjö T Konttinen. Helsinki University Central Hospital, Fourth Department of Medicine, Unioninkatu 38, SF-00170 Helsinki 17, Finland. started at the end of 1980 between Helsinki University Central Hospital and the Finnish Rheumatism Foundation Hospital for evaluation of cellular inflammation in acute, subacute, and chronic synovitis in RA by modern (immuno)histochemical methods.

\section{Materials and methods}

\section{PATIENTS AND BIOPSIES}

RA was divided into three different entities on the basis of the clinical evaluation of the duration of the disease and synovitis at the time of histopathological analysis (Table 1). We separated synovitis of recent onset into two subgroups based on the duration of the underlying RA. In cases with acute RA the duration of both the synovitis and disease was clinically less than three months. Patients with subacute RA had a well established chronic RA but no clinical symptoms or signs in the knee joint 
Table 1 Origin of the RA synovial tissue obtained for analysis

\begin{tabular}{|c|c|c|c|c|}
\hline \multirow[t]{2}{*}{$R A$} & \multicolumn{2}{|c|}{ Duration of the } & \multirow{2}{*}{$\begin{array}{l}\text { Number of } \\
\text { patients } \\
\text { studied }\end{array}$} & \multirow{2}{*}{$\begin{array}{l}\text { Method by which } \\
\text { samples were } \\
\text { obtained }\end{array}$} \\
\hline & disease & synovitis & & \\
\hline Acute & $<3$ months & $<3$ months & 4 & $\begin{array}{l}\text { Blind needle } \\
\text { biopsy }\end{array}$ \\
\hline Subacute & $>3$ years & $<3$ months & 3 & Arthroscopy \\
\hline Chronic & $>3$ years & $>3$ years & 5 & Arthrotomy \\
\hline
\end{tabular}

examined; symptoms occurred less than three months before biopsy was performed for analysis.

In each patient rheumatoid synovial tissue was taken from the knee joint. In acute and subacute RA at least three biopsy specimens were studied. Clinical data of the patients studied are given in Table 2.

A follow up of all patients continued for at least three years after biopsy. Patients classified as having acute or subacute RA developed a classic seropositive, erosive RA during the follow-up period.

\section{HISTOCHEMICAL $\alpha$-NAPHTHYL ACETATE ESTERASE (ANAE) STAINING ${ }^{11}$}

The synovial biopsy specimens were fixed in Baker's formol calcium for $20 \mathrm{~h}$, washed in Holt's solution for 4-6 h, dehydrated in acetone for $2-4 \mathrm{~h}$, and cleared in xylene for $4 \mathrm{~h}$ (all steps at $4^{\circ} \mathrm{C}$ ) before paraffin embedding for $1-2 \mathrm{~h}$ at $55^{\circ} \mathrm{C}$. Deparaffinised sections were incubated in a medium consisting of $35.6 \mathrm{ml}$ of $0.067 \mathrm{M}$ phosphate-buffered saline (PBS, pH 7.6), $2.4 \mathrm{ml}$ of hexazotised $p$ rosaniline, and $16 \mathrm{mg}$ of $\alpha$-naphthyl acetate (Sigma Chemical Co., St Louis, MO) in $2 \mathrm{ml}$ of ethylene glycol monomethyl ether acetate. The $\mathrm{pH}$ of the mixture was adjusted to $6 \cdot 1$. The incubation time was $2 \mathrm{~h}$ and counterstaining was performed in a $1 \%$ aqueous solution of toluidine blue for $5 \mathrm{~min}$ before dehydration, clearing, and mounting. Histochemic廨 staining of ANAE disclosed two different stainin patterns: one or more cytoplasmic dots (T patternf and diffuse cytoplasmic activity (M pattern).

IMMUNOHISTOCHEMICAL PAP STAINING ${ }^{12}$ For the immunoperoxidase demonstration of intraw cellular immunoglobulins (plasma cells) the synovia specimens were fixed in Bouin's fluid for 4-8 h. The tissues were then dehydrated in absolute ethanot cleared in xylene, and embedded in paraffin accordso ing to a standard histological technique. ${ }^{5}$ Paraffifir blocks were cut into $6 \mu \mathrm{m}$ thick sections. Aftec deparaffinisation the peroxidase-antiperoxidase (PAP) method was applied. Briefly, the endogenous peroxidase activity was destroyed by pretreating the sections in methanol- $\mathrm{H}_{2} \mathrm{O}_{2}$ and then treating them sequentially with: (a) normal swine serum; (b) rabbit antihuman IgG, antihuman $\kappa$ or antihuman 20 light chains; (c) swine antirabbit IgG; and ( $d \%$ rabbit antihorseradish peroxidase-horseradish perE oxidase complexes (PAP). All these antisera were purchased from Dakopatts, Copenhagen, Denmark Finally, the sections were stained according to the method of Graham and Karnovsky ${ }^{13}$ and counter黑 stained with haematoxylin.

IMMUNOHISTOCHEMICAL ABC STAINING ${ }^{11}$ The avidin-biotin-peroxidase (ABC) stainin method of Hsu et al. ${ }^{14}$ was used to identify the cell subsets in the biopsy specimens. For ABC staining

Table 2 Clinical data of the patients studied

\begin{tabular}{|c|c|c|c|c|c|c|c|c|c|}
\hline \multirow{2}{*}{\multicolumn{2}{|c|}{$R A$}} & \multirow[t]{2}{*}{ Age } & \multirow[t]{2}{*}{ Sex } & \multirow[t]{2}{*}{$A R A^{*}$ criteria } & \multirow[t]{2}{*}{$R F$} & \multirow[t]{2}{*}{ Erosions } & \multicolumn{3}{|c|}{ Synovial fluid } \\
\hline & & & & & & & $\begin{array}{l}\text { Leucocytes } \\
\times 10^{-9} / l\end{array}$ & $\begin{array}{l}M N C^{*} \\
(\%)\end{array}$ & $\begin{array}{l}P M N^{*} \\
(\%)\end{array}$ \\
\hline \multirow[t]{4}{*}{ Acute } & 1 & 63 & Male & 5 & - & - & $3 \cdot 2$ & 94 & 6 \\
\hline & 2 & 44 & Female & 6 & + & - & $8 \cdot 7$ & 22 & 78 \\
\hline & 3 & 26 & Female & 6 & + & - & $9 \cdot 2$ & 96 & 4 \\
\hline & 4 & 28 & Female & 6 & + & - & 27.8 & 77 & 23 \\
\hline \multirow[t]{3}{*}{ Subacute } & 5 & 55 & Female & 6 & + & $++^{+}$ & $15 \cdot 1$ & 30 & 70 \\
\hline & 6 & 55 & Male & 5 & - & - & $24 \cdot 0$ & 73 & 27 \\
\hline & 7 & 27 & Male & 5 & - & - & $6 \cdot 0$ & 44 & 56 \\
\hline \multirow[t]{5}{*}{ Chronic } & 8 & 31 & Male & 7 & + & + & $12 \cdot 4$ & 24 & 76 \\
\hline & 9 & 42 & Female & 7 & + & + & $8 \cdot 6$ & 16 & 84 \\
\hline & 10 & 50 & Male & 6 & + & + & $24 \cdot 0$ & 34 & 66 \\
\hline & 11 & 62 & Female & 7 & + & + & $20 \cdot 0$ & 22 & 78 \\
\hline & 12 & 38 & Male & 6 & - & + & $13 \cdot 4$ & 38 & 62 \\
\hline \multicolumn{10}{|c|}{$\begin{array}{l}\text { ARA = American Rheumatism Association; MNC = mononuclear cells; PMN = polymorphonuclear leucocytes. } \\
\text { No erosions in the joint from which the biopsy was obtained. }\end{array}$} \\
\hline
\end{tabular}


the tissue specimens were embedded in OCT compound (Lab-Tek Products, Division Miles Laboratory, Elkhart, IND) and immediately frozen in isopentane at $-50^{\circ} \mathrm{C}$. Cryostat sections were fixed in cold acetone for $5 \mathrm{~min}$. Cell surface markers were demonstrated by applying: (a) monoclonal antiserum (OKT3, OKT4, OKT8, OKIa; Ortho Pharmaceuticals Co., Raritan, NJ); (b) biotinylated horse antimouse IgG (Vector Laboratories, Burlingame, CA); and (c) ABC complexes (Vector Lab.). All antiserum incubations were performed in a humidified chamber and room temperature for 30 min. The peroxidase binding sites were shown with a fresh solution of 3,3'-diaminobenzidine tetrahydrochloride $(0.033 \%)$ and $\mathrm{H}_{2} \mathrm{O}_{2}(0.003 \%)$ in PBS for $5 \mathrm{~min}$. Tissue sections were counterstained in haematoxylin, dehydrated, cleared, and mounted.

\section{Results}

Patients with clinically different forms of RA were also segregated histopathologically into three distinct patterns (Table 3). However, because of interindividual and intrasample variations, grading of the intensity of cellular inflammation (instead of numerical evaluation as percentages of all cells) was the most rational way of expressing the findings in these three different subgroups of RA.

\section{ACUTE RA}

In acute RA the most prominent feature was the abundant occurrence of mononuclear phagocytes, especially in the sublining layer (Fig. 1). Granulocytes were also often present in patchy infiltrates and entrapped in the fibrin layer covering synovial villi (Fig. 2). Only a sparse $\mathrm{T}$ cell infiltrate was observed in the subsynovial layer.

SU B A C U T E RA

Subacute RA was histopathologically quite distinct from the acute RA. In subacute RA lymphocytes

Table 3 Inflammatory cells in different types of $R A$ synovitis

\begin{tabular}{lllll}
\hline$R A$ & \multicolumn{4}{l}{ Grading of inflammatory cells } \\
\cline { 2 - 5 } & $\begin{array}{l}\text { Mononuclear } \\
\text { phagocytes }\end{array}$ & Granulocytes & $\begin{array}{l}\text { T lympho- } \\
\text { cytes }\end{array}$ & $\begin{array}{l}\text { Plasma } \\
\text { cells }\end{array}$ \\
\hline Acute & +++ & ++ & + & - \\
Subacute & ++ & + & +++ & + \\
Chronic & + & + & +++ & +++ \\
\hline
\end{tabular}

The occurrence of cells was recorded on a scale from - (low) to ++ (high).

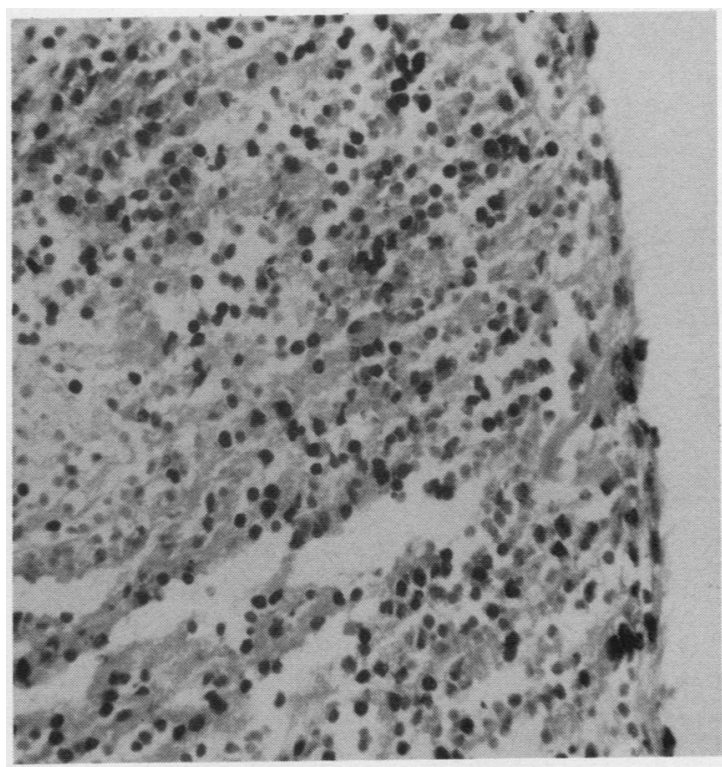

Fig. 1 Mononuclear phagocytes in acute synovitis of rheumatoid arthritis. (Esterase staining, $\times 250$ ).

were always observed in nodular perivascular infiltrates in the subsynovium (Fig. 3). Mononuclear phagocytes were also abundant in subacute RA, especially below the lining layer as shown in Fig. 3 . In the perivascular lymphocyte rich infiltrates the ANAE $^{+}, \mathrm{T}^{+} \mathrm{T}$ lymphocyte was the predominant cell. There was only a slight augmentation of $\mathrm{T}^{+}$ cells over $\mathrm{T}^{+}$cells (Fig. 4 ) as compared with the normal 2:1 ratio in the peripheral blood. Many of the local lymphocytes were $\mathrm{Ia}^{+}$(Fig. 5). In contrast to acute synovitis plasma cells also were observed in situ in subacute RA, but they were not as numerous as in chronic RA.

\section{CHRONIC RA}

An abundance of plasma cells was the most characteristic feature of chronic RA as opposed to acute and subacute synovitis, and they often formed dense infiltrates composed almost exclusively of plasma cells (Fig. 6). Mononuclear phagocytes were not as frequent as in the more acute forms - of synovitis. T cell was the predominant inflammatory cell in situ in chronic RA.

\section{HISTOPATHOLOGICAL FEATURES OF}

\section{PATIENTS}

To give some idea of variations in histology between members of the same group of patients a short description of the histopathological features in each individual patient is given below: 


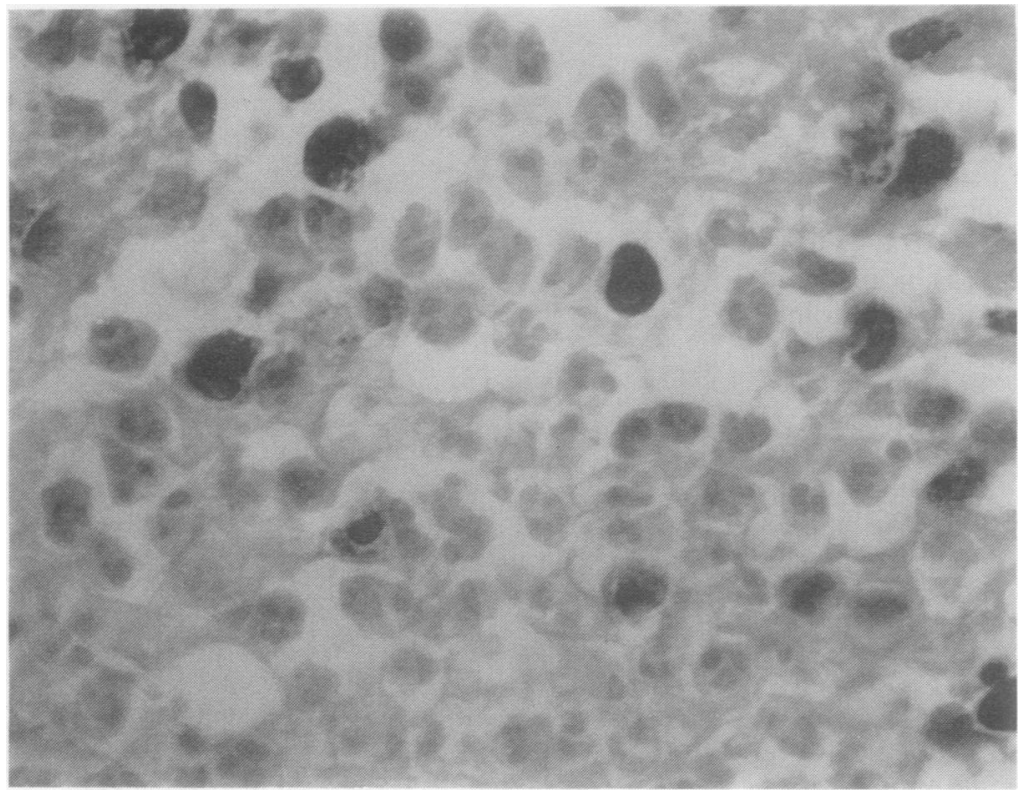

Fig. 2 A granulocyte-rich infiltrate in acute synovitis of rheumatoid arthritis. (Esterase staining, $\times 1000$ ).

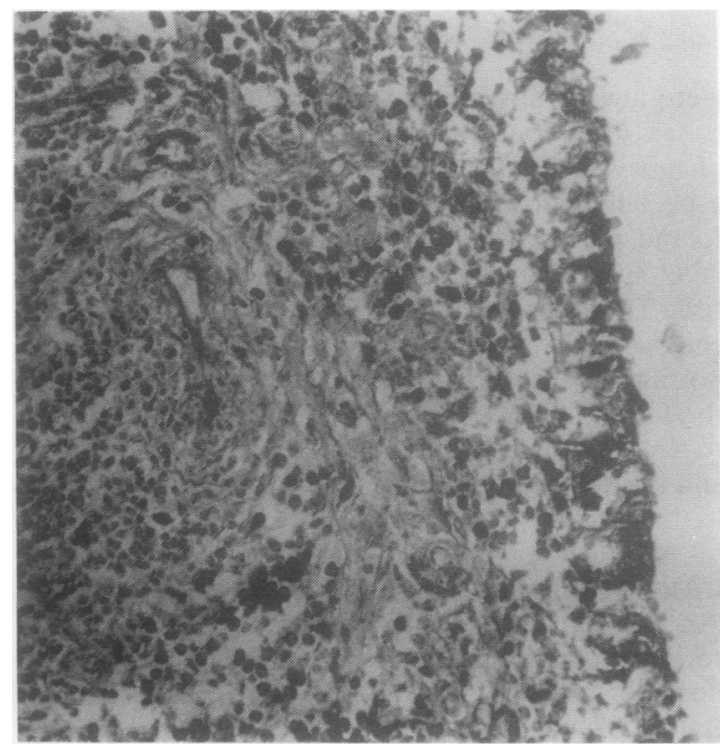

Fig. 3 Mononuclear phagocytes and a slight lymphocyte infiltrate in subacute synovitis of rheumatoid arthritis. (Esterase staining, $\times 250$ ).

\section{Acute RA}

Patient No 1. Moderate hyperplasia and hypertrophy of synoviocytes, fresh fibrin on synovial surface, oedema, proliferating capillaries, diffuse infiltrates of monocytes, some small focal aggregates of lymphocytes.
Patient No 2. Slight hyperplasia of synoviocytes, proliferating fibroblasts, diffuse infiltrates of mono-s cytes, diffuse infiltrates of granulocytes in sub-⿳亠丷厂 synoviocyte tissue.

Patient No. 3. Slight hyperplasia of synoviocytes, oedema, villi, proliferating capillaries, diffuse infil trates of monoyctes with some lymphocytes andgranulocytes.

Patient No 4. Marked hyperplasia of synoviocytes, oedema, proliferating fibroblasts, diffuse infiltrates of monocytes.

\section{Subacute $R A$}

Patient No 5. Moderate hyperplasia and hypertrophy of synoviocytes, oedema, proliferating capil-o laries, proliferating fibroblasts, focal aggregates of lymphocytes and monocytes with occasional plasmoo cells.

Patient No. 6. Slight hyperplasia of synoviocytes,, villi, proliferating fibroblasts, focal aggregates of lymphocytes, occasional monocytes and plasman cells.

Patient No 7. Moderate hyperplasia of synoviocytes fresh fibrin on synovial surface, proliferating fibroblasts, large infiltrates of lymphocytes, diffuse infiltrates of monocytes.

\section{Chronic RA}

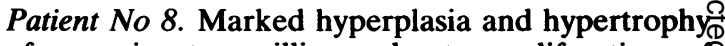
of synoviocytes, villi, moderate proliferation of fibroblasts, diffuse infiltrates of lymphocytes, 


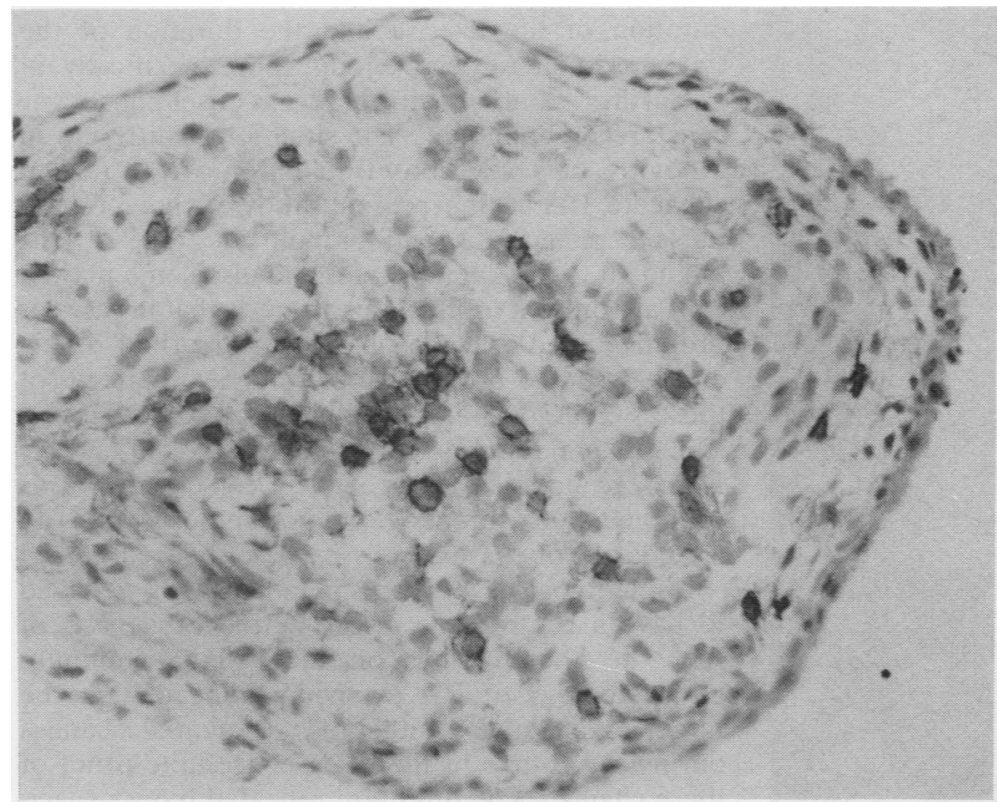

Fig. $4 \quad T 8^{+}$lymphocytes in subacute synovitis of rheumatoid arthritis. (Avidin-biotin-peroxidase staining, $\times 250$ ).

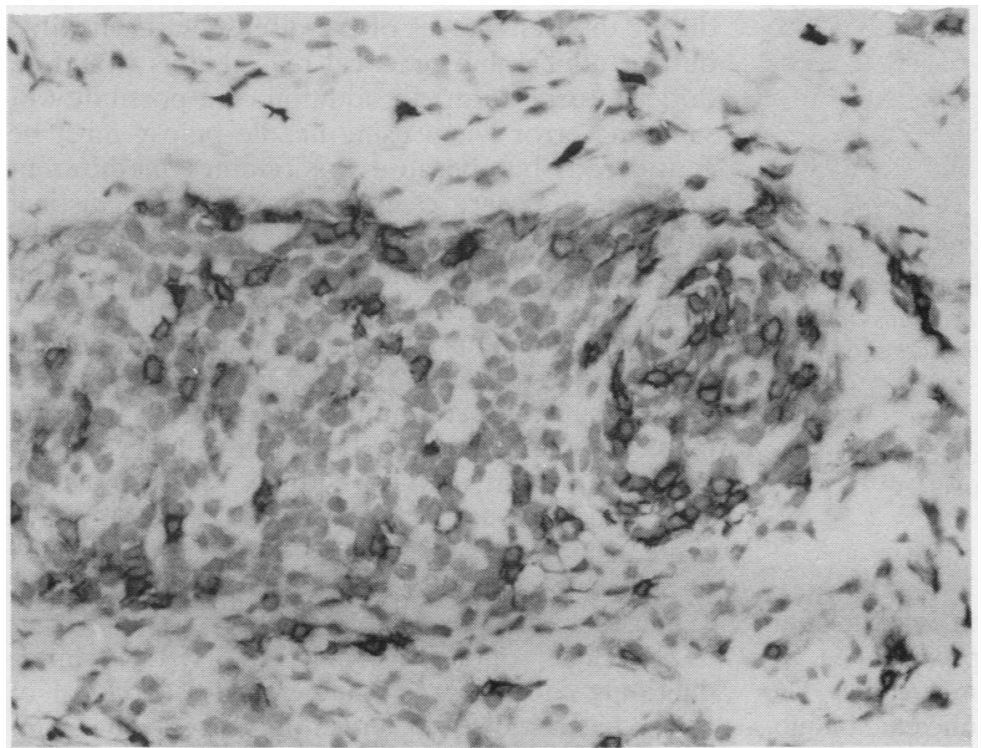

Fig. $5 \mathrm{Ia}^{+}$lymphocytes in subacute synovitis of rheumatoid arthritis. (Avidin-biotin-peroxidase staining, $\times 250$ ).

numerous plasma cells, proliferating capillaries, occasional monocytes and granulocytes.

Patient No 9. Small deposits of older fibrin scattered on synovial surface, marked hyperplasia of synoviocytes, villi, fibrosis, focal aggregates of lymphocytes and plasma cells, occasional monocytes.

Patient No 10. Marked hyperplasia and hypertrophy of synoviocytes, villi, proliferating fibroblasts, fibrosis, large infiltrates of lymphocytes and plasma cells.

Patient No 11. Slight hyperplasia of synoviocytes, fibrosis, thick walled blood vessels, diffuse infiltrates of plasma cells and lymphocytes, occasional granulocytes.

Patient No 12. Fibrin on synovial surface, marked hyperplasia of synoviocytes, villi, oedema, pro- 


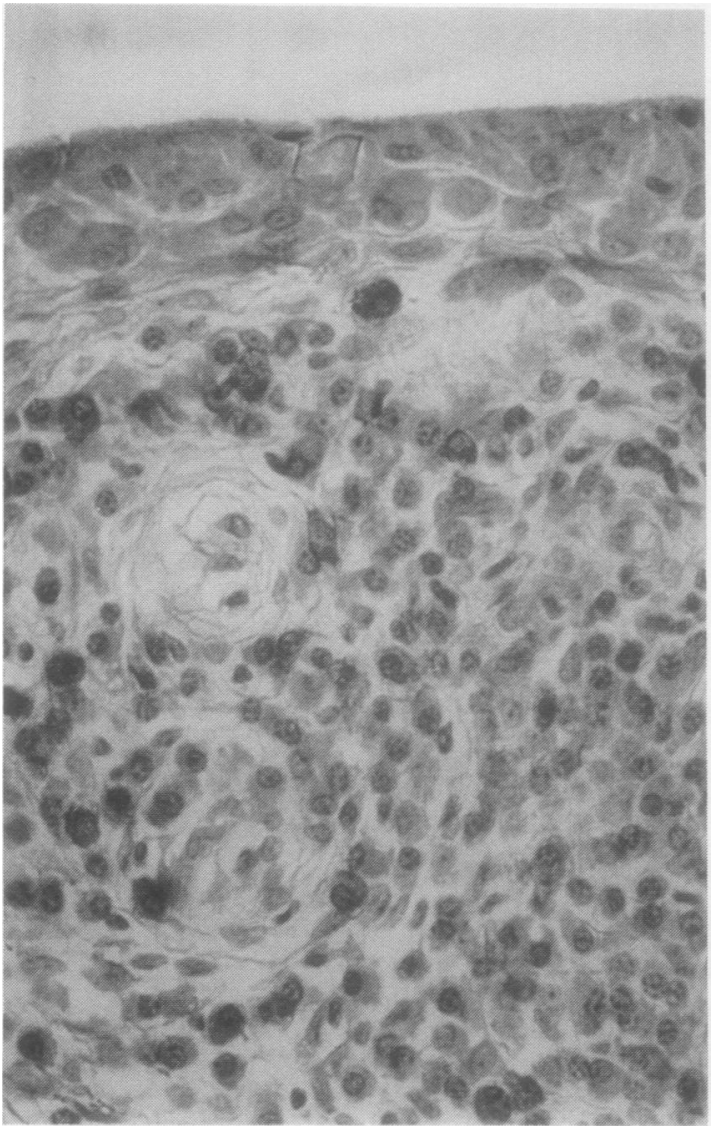

Fig. 6 K positive plasma cells in chronic synovitis of rheumatoid arthritis. (Peroxidase-antiperoxidase staining, $\times 1000)$.

liferating capillaries, dense lymphocyte and plasma cell infiltrates, occasional monocytes.

\section{Discussion}

The host response to a pathogen often consists of an inflammatory and an immune response. The inflammatory response is fast and non-specific. The neutrophilic leucocytes and mononuclear phagocytes have been distinguished as the main protagonists of inflammation. ${ }^{15} 16$ The immunological response is slower but it is characterised by specificity and memory. Immunocompetent cells, i.e., $T$ and $B$ lymphocytes, are the cellular mediators of the immune response. ${ }^{17}$ According to our findings these generally valid principles seem to apply to the cellular immunohistopathology of rheumatoid arthritis, too.

Our findings indicate that rheumatoid arthritis develops distinct stages depending on both the duration of the disease and the duration of the synovitis in the respective joint. More specifically, in RA arthritis and synovitis of recent onset phagocytic cells are predominant. The situation is different in synovitis of recent onset in chronic RA (callect. subacute RA in the present study), where mono $\frac{\vec{\sigma}}{\sigma}$ nuclear phagocytes and granulocytes are not as abundant, but $\mathrm{T}$ lymphocytes and also some plasman cells are present in situ. This suggests that in cases of prolonged RA the reasons for the marked differences observed in the histopathological patterns of $\overrightarrow{\mathrm{f}}$ these two entities are subclinical synovial changes The inflammation in prolonged synovitis in chroniç RA is compatible with an active $T$ cell dependent, $B_{+}^{+}$ cell mediated immunoglobulin synthesis with ario abundance of plasma cells as described earlier. ${ }^{1-8}$

Immunological mechanisms are usually believed to have a central role in the aetiopathogenesis of RA. ${ }^{18} 19$ Our findings on the cellular immunohistopathology of RA synovium indicate that the target organ in RA undergoes sequential changes: during the course of the disease. Definite proof of ${ }^{f}$ these changes would require repeated biopsy speci $\vec{\circ}$ mens from the same patients and the same joinţ during different stages of the disease and synovitis, but for ethical and practical reasons this would be difficult to perform. In addition, the possibility of sampling error when using needle biopsy must ben considered, but because the findings in differento forms of RA were clearly segregated into distinct subgroups, we concluded that they present differen? phases of the disease and synovitis. This finding and earlier observations on synovitis of recent onset ${ }^{9}{ }^{19}$ suggest that immunological mechanisms are not the initial unknown cause of RA. Our findings sugges 5 rather that cellular immune mechanisms becomé involved as a reaction to the tissue damage caused. by the initial inflammatory attack. This applies in some other diseases with known exogenous patho genic agents which also activate the immunologicab response of the host against autologous but damaged tissue.

The close contact between HLA-D/DR ${ }^{+}$inter digitating cells and $\mathrm{T}^{+}$helper cells so typical op $\mathrm{RA}^{46}$ has also been observed in non-specific syno $N$ vitis, such as traumatic and crystal arthritis. ${ }^{20}$ Thi\$ suggests that immunological mechanisms are not necessarily the initial unknown cause of $R A,{ }^{21}$ but they may still have a central role in the aetiopatho genesis of RA. Therefore, the crucial question 'Howe? does RA start?' should perhaps be replaced by 'Whyo doesn't it stop?'. Certainly the most characteristio feature of RA synovitis is the intensity and chronicity of the inflammation. This might be due to defectived down-regulation of the immune response in $\mathrm{RA}_{\sigma}$ Actually, experiments in vitro have shown that the 
production of both suppressor $\mathrm{T}$ cells ${ }^{22} 23$ and also cytotoxic $\mathrm{T}$ cells ${ }^{24} 25$ is deficient in RA. Furthermore, we have recently observed that the activation of $\mathrm{T}^{+}$suppressor/cytotoxic cells is defective in chronic RA in vivo. ${ }^{26}$ This is not the case in reactive arthritis (manuscript in preparation). In addition, the cellular immunohistopathology of RA at different developmental phases does not show any disease-specific changes. These observations indicate further that deficient production of terminal effector cells may be the cause of (the chronicity of) RA.

This study was supported by the Finnish Foundation For Rheumatic Disease, Finska Läkaresällskapet, Finnish Academy of Sciences. Helsinki University, and Hoechst Fennica.

\section{References}

1 Abrahamsen T G, Frøland S S, Natvig J B, Pahle J. Elution and characterization of lymphocytes from rheumatoid inflammatory tissue. Scand J Immunol 1975; 4: 823-30.

2 Førre $\mathrm{O}$, Thoen $\mathrm{J}$, Lea $\mathrm{T}$, et al. In situ characterization of mononuclear cells in rheumatoid tissues, using monoclonal antibodies. No reduction of T8-positive cells or augmentation in T4-positive cells. Scand J Immunol 1982; 16: 315-9.

3 Gardner D L. Pathology of the connective tissue diseases. London: Arnold, 1965.

4 Janossy G, Panayi G, Duke O, Bofill M, Poulter L W, Goldstein G. Rheumatoid arthritis: a disease of T lymphocytemacrophage immunoregulation. Lancet 1981; ii: 839-42.

5 Julkunen H. Synovial inflammatory reaction in chronic arthritis Acta Rheumatol Scand 1966; 12: 188-96.

6 Klareskog L, Forsum U, Wigren A, Wigzell H. Relationships between HLA-DR-expressing cells and $T$ lymphocytes of different subsets in rheumatoid synovial tissue. Scand $J$ Immunol 1982; 15: 501-7.

7 Konttinen Y T, Reitamo S, Ranki A, Häyry P, Kankaanpää U, Wegelius $\mathrm{O}$. Characterization of the immunocompetent cells of rheumatoid synovium from tissue sections and eluates. Arthritis Rheum 1981; 24: 71-9.

8 van Boxel J A, Paget S A. Predominantly T-cell infiltrate in rheumatoid synovial membranes. N Engl J Med 1975; 293: 517-20.

9 Kulka J P, Bocking D, Ropes M W, Bauer W. Early joint lesions in rheumatoid arthritis. Report of eight cases with knee biopsies of lesions of less than one year's duration. Arch Pathol Lab Med 1955; 59: 129-50.

10 Schumacher H R, Kitridou R C. Synovitis of recent onset. A clinicopathologic study during the first month of disease. Arthritis Rheum 1972; 15: 465-85.
11 Konttinen Y T, Bergroth V, Visa-Tolvanen K. Reitamo S. Förström L. Cellular infiltrate in situ and response kinetics of human intradermal and epicutaneous tuberculin reactions. Clin Immunol Immunopathol 1983; 28: 441-9.

12 Bergroth V. Immunoperoxidase and related techniques. Evaluation of methodology and application to quantitative kinetic studies of immunocompetent cells. Helsinki: University of Helsinki, 1983. (Thesis).

13 Graham R C, Karnovsky M J. The early stages of absorption of injected horseradish peroxidase in the proximal tubules of mouse kidney: ultrastructural cytochemistry by a new technique. J Histochem Cytochem 1966; 14: 291-302.

14 Hsu S-M, Raine L, Fanger $H$. Use of avidin-biotin-peroxidase complex $(\mathrm{ABC})$ in immunoperoxidase techniques: a comparison between $\mathrm{ABC}$ and unlabelled antibody (PAP) procedures. $J$ Histochem Cytochem 1981; 29: 577-80.

15 Peltola P. Effects of corticosteroid pulse therapy on inflammatory mechanisms. Scand J Rheumatol 1984; 54 (suppl): 10-2.

16 Ziff M. Phagocytes and substrates in the joint. Scand $J$ Rheumatol 1981; 40 (suppl): 10-2.

17 Strober S. Immunologic aspects of inflammation: lymphocyte subpopulations. In: Kelley W W, Harris E D Jr, Ruddy S, Sledge C B, eds. Textbook of rheumatology. Philadelphia: Saunders, 1981: 19-31.

18 Konttinen Y T, Zvaifler N J. Rheumatoid synovitis: a perpetuated articular autologous mixed leukocyte reaction (Editorial) Scand $J$ Rheumatol in preparation.

19 Silver $\mathrm{R} \mathrm{M}$, Zvaifler N J. Immunologic pathogenesis of rheumatoid arthritis. In: Utsinger P D, Zvaifler N J, Ehrlich G, eds. Rheumatoid arthritis. Philadelphia: Lippincott, (in press).

20 Lindblad S, Klareskog L, Hedfors E, Forsum U, Sundström C. Phenotypic characterization of synovial tissue cells in situ in different types of synovitis. Arthritis Rheum 1983; 26: 1321-32.

21 Ahlqvist J. Can increased generalized vascular leakage in ambulant individuals induce joint effusions, synovitis, hypoxia and destruction? Scand J Rheumatol 1984; 52 (suppl): 86-92.

22 Chattopadhyay C, Chattopadhyay H, Natvig J B, Mellbye O J. Rheumatoid synovial lymphocytes lack concanavalin-Aactivated suppressor cell activity. Scand J Immuol 1979; 10: $479-86$.

23 Chattopadhyay C, Chattopadhyay H, Natvig J B, Michaelsen T E, Mellbye O J. Lack of suppressor cell activity in rheumatoid synovial lymphocytes. Scand J Immunol 1979; 10: 309-16.

24 Konttinen Y T, Bluestein H G, Zvaifler N J. Regulation of the growth of Epstein-Barr virus infected B cells: growth regression by E-rosetting cells from VCA-positive donors is a combined effect of autologous mixed leukocyte reaction änd activation of $\mathrm{T}^{+}$memory cells. J Immunol 1985; 134: 2287-93.

25 Konttinen $\mathrm{Y} \mathrm{T}$, Bluestein $\mathrm{H} \mathrm{G}$, Zvaifler $\mathrm{N}$ J. Impaired regression of $\mathrm{B}_{\mathrm{EBV}}$ outgrowth by $\mathrm{VCA}^{+} \mathrm{RA}$ lymphocytes is due to diminished development of $\mathrm{T}^{+}, 4 \mathrm{~F}^{+}$cytotoxic cells [abstract]. Scand J Rheumatol 1984; 53 (suppl): 119.

26 Konttinen Y T, Bergroth V, Nykänen P. Lymphocyte activation in rheumatoid arthritis synovial fluid in vivo. Scand $J$ Immunol (in press). 